\title{
Evaluation of a Set of Hordeum vulgare subsp. spontaneum Accessions for $\beta$-Glucans and Microelement Contents
}

\author{
Fadwa Elouadi ${ }^{1, *(\mathbb{D}}$, Ahmed Amri ${ }^{2, *}$, Adil El-baouchi ${ }^{3}$, Zakaria Kehel ${ }^{2} \mathbb{D}$, Ghizlanne Salih ${ }^{4}$, Abderrazek Jilal ${ }^{4}$, \\ Benjamin Kilian ${ }^{5}$ (D) and Mohammed Ibriz ${ }^{1}$ \\ 1 Plant, Animal Productions and Agro-Industry Laboratory, Ibn Tofail University, P.O. Box 133, \\ Kénitra 14000, Morocco; m_ibriz@yahoo.fr \\ 2 International Center for Agricultural Research in the Dry Areas, Hafiane Cherkaoui Avenue, P.O. Box 6299, \\ Rabat 10101, Morocco; Z.Kehel@cgiar.org \\ 3 African Integrated Plant and Soil Research Group (AiPlaS), AgroBioSciences, \\ Mohammed VI Polytechnic University, Ben Guerir 43150, Morocco; Adil.ElBaouchi@um6p.ma \\ 4 National Institute for Agricultural Research, Regional Center of Rabat, P.O. Box 6570, Rabat 10101, Morocco; \\ gh.salih@yahoo.fr (G.S.); Abderrazek.jilal@inra.ma (A.J.) \\ 5 Global Crop Diversity Trust, Platz der Vereinten Nationen 7, D-53113 Bonn, Germany; \\ benjamin.kilian@croptrust.org \\ * Correspondence: fadwa.elouadi@uit.ac.ma (F.E.); a.amri@cgiar.org (A.A.)
}

\section{check for} updates

Citation: Elouadi, F.; Amri, A.; El-baouchi, A.; Kehel, Z.; Salih, G.; Jilal, A.; Kilian, B.; Ibriz, M. Evaluation of a Set of Hordeum vulgare subsp. spontaneum Accessions for $\beta$-Glucans and Microelement Contents. Agriculture 2021, 11, 950. https://doi.org/10.3390/ agriculture 11100950

Academic Editor:

Massimiliano Renna

Received: 25 August 2021

Accepted: 24 September 2021

Published: 30 September 2021

Publisher's Note: MDPI stays neutral with regard to jurisdictional claims in published maps and institutional affiliations.

Copyright: (c) 2021 by the authors. Licensee MDPI, Basel, Switzerland. This article is an open access article distributed under the terms and conditions of the Creative Commons Attribution (CC BY) license (https:// creativecommons.org/licenses/by/ $4.0 /)$.
Abstract: Barley is one of the oldest domesticated crops in the world and is mainly used for feed and malt and to a lesser extent as food. The use of barley as food is a tradition in communities in some countries of North Africa, Europe, and Asia. However, due to the health-promoting properties of barley grain, there is an increasing interest in such use. The International Center for Agricultural Research in the Dry Areas (ICARDA) has a global mandate for barley improvement and holds rich in-trust collections of cultivated and wild Hordeum species. The present study aims to evaluate 117 accessions of Hordeum spontaneum for their contents of $\beta$-glucan and microelements for breeding new varieties with enhanced nutritional value. The bulked seed accessions of Hordeum spontaneum were grown over two seasons, and the single plant derived seeds from these accessions were compared to 36 elite lines and varieties of cultivated barley in the second season in Morocco. The results showed large differences in $\beta$-glucan and microelements in both the bulk and the single plant seed accessions. The contents of $\beta$-glucans ranged from 1.44 to $11.3 \%$ in the Hordeum spontaneum accessions and from 1.62 to $7.81 \%$ in the cultivated barley lines. Large variations were found for the microelements content, but no differences were noticed between the wild and the cultivated species. However, some accessions of Hordeum spontaneum had higher combined contents of Iron, Zinc, and Selenium. Such accessions are used in interspecific crosses to develop biofortified barley germplasm and varieties.

Keywords: barley; $\beta$-glucan; biofortification; genetic resources; trace element; wild barley

\section{Introduction}

Biofortification of major staple crops is increasingly stressed as a mean to overcome the prevailing hunger and malnutrition, mainly in developing countries. Enhancement of micronutrients and vitamin contents in the diets can be achieved through supplementation, diversification of food sources, and use of appropriate fertilizers, most of which are not affordable to small holder farmers [1]. Genetic biofortification is a more sustainable approach to alleviate hidden hunger. Several initiatives including the Biofortification Challenge Program and Harvest Plus (https: / / www.harvestplus.org/ accessed on 23 September 2021) were supporting CGIAR centers to develop varieties with enhanced contents of micronutrients. Both traditional breeding and transgenic approaches are used in improving the micronutrient contents. The first biofortified varieties were developed in case of rice, wheat, 
cassava, maize, beans, and sweet potatoes, and pre-breeding efforts are recently undertaken for many other crops including lentil and barley (CGIAR 2018).

Barley (Hordeum vulgare subsp. vulgare), was domesticated more than 10,000 years ago by early human communities in the Fertile Crescent [2]. Barley has been since pre-historic time a part of a sustainable food source for humans [3]. The domesticated form of barley and its wild progenitor (Hordeum vulgare subsp. spontaneum) were both important foodstuffs along with Spelt, Emmer, and Einkorn in ancient civilizations according to archaeological research [4]. Because of its rich dietary fiber, barley was awarded to the gladiators also called as barley men or "hordearii" [5]. Barley is adapted to harsh environments and grown unlike other cereals in a wider range of conditions. It is grown further toward the poles, into deserts, and at higher elevations [6]. It is a major world crop, ranking the fourth among cereals and fifth overall in millions of tons produced per year [6]. Barley production is widely distributed around the world, with $64 \%$ of the world production is in Europe, including the Russian Federation [6]. Barley is an important feed for animals as green forage, grain, and straw, and its grain is used by malting and brewing industries. Because of its adaptation to high altitudes, drought, and soil salinity, it is considered as a staple food in many regions [7]. The use of barley as food is ranked third behind its use as animal feed and in malting and alcohol production in the United States [8]. Recent research is promoting the use of barley as food and because of its health claims [9].

Barley kernel contains about $65-68 \%$ starch, $10-17 \%$ proteins, $4-9 \% \beta$-glucans, $2-3 \%$ free lipids, and $1.5-2.5 \%$ minerals [10]. Many health benefits were attributed to barley and its content of $\beta$-glucan, such as cardiovascular diseases via cholesterol lowering and improvement of glucose tolerance [11]. $\beta$-glucan is a soluble fiber made up of unbranched polysaccharides with (1-4) and (1-3) linked b-D-glucopyranosyl units in varying proportions [12]. Oat and barley are among the cereals that contain the highest levels of $\beta$-glucan at $3-7 \%$ and $3-11 \%$, respectively [12]. For the cultivated barley, high $\beta$-glucan content is associated with a locus on chromosome $2(2 \mathrm{H})$ as reported by [13]. Besides its high content of soluble fibers, other nutritional attributes can also be found in barley, such as vitamins and micronutrients [3]. Specifically, Iron and Zinc are acclaimed as two of the micronutrient deficiencies in humans' diets all over the world [14]. Two billion people in the world are affected by micronutrient malnutrition, known as the "Hidden hunger" [3]. Cereal-based foods are consumed worldwide as the main source of calories, but they naturally have very low concentrations and bioavailability of Iron and Zinc, especially when grown in mineralpoor soils [15]. Genetic and genomic tools are used to develop micronutrient-enriched cereals to decrease malnutrition [16].

Barley, as one of the most adapted crops to harsh environments, is promoted as a climate smart crop and can therefore contribute to sustain food and nutritional security. Improved varieties with higher and stable yields, resistant to major pests and diseases and having good end-use quality attributes are key to boost the production and use of barley. However, further genetic gain in breeding programs will require broadening of the genetic base through access to genetic resources and gene discovery and transfer [17]. The genetic resources conserved ex situ in several genebanks could play a key role in enhancing genetic diversity and ICARDA's genebank holds in-trust one of the largest collections of barley including a unique collection of Hordeum spontaneum (GENESYS, 2020). Hordeum spontaneum is the direct progenitor of cultivated barley and the only wild species in the barley primary genepool [18]. This wild species has been extensively used in the past to transfer genes for disease resistance and drought tolerance, but has hardly been used to improve quality and nutritional properties [19]. Ref. [3] Have reported that although wild barley is a great source of many desirable traits, it is still not suitable for breeding because of the linkage of "undesirable" alleles with agronomically or nutritionally important traits.

This study aimed to evaluate of a set of Hordeum spontaneum accessions for $\beta$-glucans contents and mineral content together with cultivars and elite lines of barley to use them as parents for breeding bio-fortified barley cultivars. 


\section{Materials and Methods}

\subsection{Genetic Material}

A total of 117 accessions of wild barley (Hordeum vulgare subsp. spontaneum) were selected from ICARDA's genebank to represent 21 countries scattered along the natural geographic distribution of the species (Table 1). In addition, 36 genotypes of cultivated barley representing elite germplasm and cultivars released were also used for comparison in 2018.

Table 1. Number of accessions and country of origin of accessions of Hordeum spontaneum evaluated in 2017 and 2018 seasons.

\begin{tabular}{lcc}
\hline \multicolumn{1}{c}{ Origin } & $\mathbf{2 0 1 7}$ & $\mathbf{2 0 1 8}$ \\
\hline Afghanistan (AFG) & 3 & 4 \\
Armenia (ARM) & 1 & 1 \\
Azerbaijan (AZE) & 2 & 2 \\
China (CHN) & 2 & 3 \\
Cyprus (CYP) & 2 & 2 \\
Egypt (EGY) & 1 & 4 \\
Iran (IRN) & 4 & 4 \\
Iraq (IRQ) & 3 & 8 \\
Israel (ISR) & 7 & 14 \\
Jordan (JOR) & 14 & 5 \\
Kazakhstan (KAZ) & 5 & 1 \\
Lebanon (LBN) & 1 & 15 \\
Libya (LBY) & 12 & 2 \\
Pakistan (PAK) & 2 & 2 \\
Palestine (PSE) & 2 & 1 \\
Russia (RUS) & 1 & 14 \\
Syria (SYR) & 14 & 23 \\
Tajikistan (TJK) & 21 & 4 \\
Turkmenistan (TKM) & 5 & 3 \\
Turkey (TUR) & 2 & 1 \\
Uzbekistan (UZB) & 1 & \\
\hline
\end{tabular}

The two experiments were planted at ICARDA's Marchouch station in Morocco $\left(33^{\circ} 36^{\prime} \mathrm{N} 6^{\circ} 42^{\prime} \mathrm{W}, 390\right)$, the soil tests showed neutral nature of the soil with $\mathrm{pH}$ of 7.6 and the contents of microelements were $20 \mathrm{ppm}$ for Iron, $1.5 \mathrm{ppm}$ for Zinc, $5.5 \mathrm{ppm}$ for Manganese, and $0.7 \mathrm{ppm}$ for Copper. By choosing a homogeneous site for conducting the trials, we believe that the genotypes are mainly expressing their genetic differences.

The first experiment included 117 accessions of the original bulked seeds and evaluated over two seasons (2015_16 and 2016_17). The second experiment was composed of 113 entries each derived from seeds of a single plant taken at random from the original accession of Hordeum spontaneum to be compared to 36 entries of cultivated samples during the 2016_17 season. Each entry is planted in two rows of $2 \mathrm{~m}$ long with row spacing of $0.3 \mathrm{~m}$ and $1.4 \mathrm{~m}$ between adjacent accessions in a non-replicated trial. The experiments were conducted under optimal conditions with irrigation when necessary. The management of the trials followed the recommended agronomic package (sowing in November $40 \mathrm{Kg} / \mathrm{ha}$ of nitrogen at sowing and $40 \mathrm{Kg} / \mathrm{ha}$ at the end of tillering). Herbicide and manual weeding were applied to control weeds and fungicides were used to control foliar diseases. Each wild Hordeum spontaneum accession was hand harvested before shattering and the grains were de-awned and dried to less than $7 \%$ relative humidity in a dehumidified room prior to evaluation. For cultivated barley, the samples of each entry were manually harvested then threshed using a stationary thresher and the grains were cleaned, de-awned, and dried to less than $7 \%$ relative humidity. 


\subsection{Grain Sample Preparation}

Dried and cleaned grains were grinded using a laboratory cyclone mill (Retsch Cyclone Mill Twister) with a sieve of $1 \mathrm{~mm}$. The grinding mill was cleaned before and after milling each sample to avoid cross contamination. The moisture content of each sample was determined according to the AACC conventional method [20].

\section{3. $\beta$-Glucan Determination}

The $\beta$-glucan content was determined according to a fluorometric method using a continuous flow analyzer (SKALAR san++). Prior to this determination, an acid extraction was performed using the procedure recommended by the European Brewery Convention [21]. $100 \mathrm{mg}$ of the whole grain flour was weighed in a tube $(50 \mathrm{~mL}) .10 \mathrm{~mL}$ of distillated water was added together with $100 \mu \mathrm{L}$ of alpha-amylase, dispersed using a vortex mixer, then, the tube was boiled for one hour in a water bath, cooled, then $10 \mathrm{~mL}$ of sulfuric acid is added, the content is homogenized and boiled for another $10 \mathrm{~min}$, cooled to room temperature, and then centrifuged for $10 \mathrm{~min}$ at $3000 \mathrm{rpm}$. An aliquot of the clear filtered supernatant is loaded into the sampler of the continuous flow analyzer. The extract was pumped and injected in the $\beta$-glucan module alongside with the reagents prepared previously and mixed together, then the mixture passed through the flow cell of the fluorimeter for the lecture. The signal was fed to a computer equipped with a specific software analysis system, and quantification is based on the calibration curve.

\subsection{Microelement Content}

The determination of microelements content was performed according to a standard protocol [22]. The whole grain flour $(500 \mathrm{mg})$ was placed in a digestion tube and left overnight after adding $8 \mathrm{ml}$ of nitric acid $\left(\mathrm{HNO}_{3}\right)$, then heated at $90{ }^{\circ} \mathrm{C}$ for $60 \mathrm{~min}$ and $3-4 \mathrm{~mL}$ of hydrogen peroxide $30 \%$ is added. Once the solution is colorless, the digestion process is stopped and the digest was filtered after cooling, and diluted with hydrochloric acid $(\mathrm{HCl})$. The elemental determination was carried out with a simultaneous multi-element inductively coupled plasma-optical emission spectrometer (iCAP-7000 Duo, Thermo Fisher 149 Scientific) which detects several element simultaneously. The ICP-OES provides concentration assays for several elements as for us (Iron, Zinc, Selenium, Potassium, Sodium, Calcium, Magnesium, Manganese, and Copper) evaluated in this study.

\subsection{Statistical Analysis}

Bulks of wild accessions were evaluated in 2017 and 2018 using multiple samples per accession, while the single plants of the same wild accession and cultivated barley germplasm were evaluated in 2018 only using a single sample per accession. The seeds used were from ICARDA's genebank regeneration trial.

Data from bulked wild accessions were analyzed using a linear mixed model with accession as fixed effects and the year together with the sample within the year, were both considered as random effects. Best linear unbiased estimators BLUEs were extracted together with $p$-values for the accessions effect. The analysis was performed using AsREML v3.0-1 [23] for R v3.3.1 [24].

Spearman correlations were then computed between the traits of the different sets of the accessions (wild bulk, and wild single plant and cultivated).

The density distributions were compared between the accessions of Hordeum spontaneum as bulk and single plant seeds and the cultivated barley germplasm using $\mathrm{R}$ sm package [25].

\section{Results}

\subsection{Analysis of Variance and Descriptive Statistics}

The analysis of variance showed very significant differences between accessions as bulk seeds for $\beta$-glucan content and for all the microelements (Table 2). Heritabilities were 
significant for all traits except for Copper (0.13) and Calcium contents (0.01). The highest heritability was for $\beta$-glucan $(h=0.71$ ) followed by Potassium (0.50), Magnesium (0.47), and the other heritabilities were significant, ranging from 0.28 to 0.34 for Zinc, Iron, and Selenium.

Table 2. Sum of squares, significance level and heritabilities of $\beta$-glucan and microelements of Hordeum spontaneum bulk accessions harvested from Marchouch during 2016_17 and 2017_18 seasons.

\begin{tabular}{|c|c|c|c|c|c|c|}
\hline \multicolumn{2}{|c|}{ Trait } & \multirow{3}{*}{$\begin{array}{l}\text { Df } \\
117 \\
\text { NA }\end{array}$} & \multirow{3}{*}{$\begin{array}{c}\text { Sum of Sq. } \\
8679.44 \\
1.02\end{array}$} & \multirow{3}{*}{$\begin{array}{c}\text { Wald Statistic } \\
8531.61 \\
\text { NA }\end{array}$} & \multirow{3}{*}{$\begin{array}{c}\operatorname{Pr}(\text { Chisq) } \\
0 \\
\text { NA }\end{array}$} & \multirow{3}{*}{$\begin{array}{c}\text { Heritability } \\
0.71\end{array}$} \\
\hline R-oll1san & Genotype & & & & & \\
\hline ß-glucan & residual (MS) & & & & & \\
\hline \multirow{2}{*}{ Zinc } & Genotype & 117 & $11,112.86$ & 202.84 & $1.48 \times 10^{-6}$ & \multirow{2}{*}{0.28} \\
\hline & residual (MS) & NA & 54.79 & NA & NA & \\
\hline \multirow{2}{*}{ Iron } & Genotype & 117 & $20,468.05$ & 223.20 & $1.23 \times 10^{-8}$ & \multirow{2}{*}{0.32} \\
\hline & residual (MS) & NA & 91.70 & NA & NA & \\
\hline \multirow{2}{*}{ Potassium } & Genotype & 117 & $99,599,667.78$ & 273.66 & $1.41 \times 10^{-14}$ & \multirow{2}{*}{0.50} \\
\hline & residual (MS) & NA & $363,954.09$ & NA & NA & \\
\hline \multirow{2}{*}{ Sodium } & Genotype & 117 & $1,347,813.47$ & 157.73 & 0.00721002 & \multirow{2}{*}{0.18} \\
\hline & residual (MS) & NA & 8545.24 & NA & NA & \\
\hline \multirow[b]{2}{*}{ Calcium } & Genotype & 117 & $534,167.47$ & 167.03 & 0.00165895 & \multirow[b]{2}{*}{0.01} \\
\hline & residual (MS) & NA & 3198.06 & NA & NA & \\
\hline \multirow{2}{*}{ Magnesium } & Genotype & 117 & $35,176,519.28$ & 266.74 & $1.05 \times 10^{-13}$ & \multirow{2}{*}{0.47} \\
\hline & residual (MS) & NA & $131,876.18$ & NA & NA & \\
\hline \multirow{2}{*}{ Manganese } & Genotype & 117 & 1580.19 & 187.04 & $4.18 \times 10^{-5}$ & \multirow{2}{*}{0.30} \\
\hline & residual (MS) & NA & 8.45 & NA & NA & \\
\hline \multirow{2}{*}{ Copper } & Genotype & 117 & 1990.87 & 202.4 & $1.62 \times 10^{-6}$ & \multirow{2}{*}{0.13} \\
\hline & residual (MS) & NA & 9.83 & NA & NA & \\
\hline \multirow{2}{*}{ Selenium } & Genotype & 117 & 2.39 & 292.42 & 0 & \multirow[b]{2}{*}{0.34} \\
\hline & residual (MS) & NA & 0.01 & NA & NA & \\
\hline
\end{tabular}

Table 3 summarized the mean, range, and standard deviation of dietary fiber and microelement contents in flour. For $\beta$-glucan, its content expressed as percentage varied from 1.82 to $10.37 \%$ with an average over two seasons of $6.94 \%$ (Table 3). Eighteen accessions had high $\beta$-glucan content above 8\%, including four accessions IG 144997, IG 38679, IG 145604, and IG 38658 with contents of 10.37, 10.35, 10.32, and 10.05\%, respectively (Appendix A).

Table 3. Mean, standard deviation and range of $\beta$-glucan and microelement contents in the flour of Hordeum spontaneum bulk accessions harvested from Marchouch during 2016_17 and 2017_18 seasons.

\begin{tabular}{lccc}
\hline \multicolumn{1}{c}{ Trait } & Mean & Minimum & Maximum \\
\hline B-glucan (\%) & $6.94 \pm 1.35$ & 1.85 & 10.37 \\
Iron (ppm) & $47.62 \pm 6.83$ & 24.40 & 66.40 \\
Zinc (ppm) & $30.22 \pm 6.10$ & 17.56 & 53.05 \\
Selenium (ppm) & $0.28 \pm 0.07$ & 0.17 & 0.51 \\
Magnesium (ppm) & $1689.86 \pm 303.24$ & 1193.63 & 3425.85 \\
Manganese (ppm) & $18.74 \pm 2.14$ & 12.85 & 24.67 \\
Potassium (ppm) & $2544.74 \pm 512.77$ & 487.09 & 3590.18 \\
Sodium (ppm) & $365.63 \pm 71.85$ & 235.07 & 608.07 \\
Calcium (ppm) & $562.08 \pm 44.07$ & 465.48 & 742.54 \\
Copper (ppm) & $16.87 \pm 2.22$ & 8.17 & 22.89 \\
\hline
\end{tabular}

For the microelements, the differences between the minimum and maximum values ranged from about two folds for the majority of micronutrients to seven folds for Potassium (Table 3). Accessions with the highest contents for microelements were: IG 144913, IG 38859, IG 39962, and IG 38826 for Iron with values exceeding 57 ppm; IG 39859, IG 144117, and IG 145504 for Zinc having respective contents of 53.05, 46.92, and 46.66 ppm; IG 131620, IG 144121, IG 132489, IG 44095, IG 131643, and IG 116005 for Zinc with values exceeding 
35 ppm; IG 135624, IG 39884, IG 135624, IG 129152, IG 145523, and IG 40107 and for Selenium with values ranging from 0.45 to 0.51 ppm; IG 145155, IG 135624, IG 39884, IG 145498, and IG 145556 for Magnesium with values exceeding 2400 ppm (Appendix A). For the other elements, the highest values were shown by IG 39,934 (742.54 ppm) for Calcium, IG 39933 (22.89 ppm) for Copper, IG 39884 (24.67 ppm) for Manganese, IG 144997 (3590.18 ppm) for Potassium, and IG 144913 (608.07 ppm) for Sodium.

In 2017_18, accession of the Hordeum spontaneum were planted together as bulk and single plant derived seeds together with cultivars and elite germplasm and their contents of $\beta$-glucan, and microelements were compared. Pearson's correlations between bulked and single plant derived seeds of wild accessions were significant only for $\beta$-glucan $(0.32$, $p$-value $<0.001)$ and Copper content $(0.22, p$-value $<0.05)($ Table 4$)$.

Table 4. Pearson's correlations between bulk and single plant derived seeds of Hordeum spontaneum accessions for $\beta$-glucan and microelements.

\begin{tabular}{cc}
\hline & $\mathbf{R}$ \\
\hline B-glucan & $0.32^{* * *}$ \\
Iron & -0.11 \\
Zinc & -0.12 \\
Selenium & -0.04 \\
Magnesium & 0.16 \\
Manganese & 0.14 \\
Potassium & -0.11 \\
Sodium & 0.04 \\
Calcium & 0.04 \\
Copper & $0.22^{*}$ \\
\hline
\end{tabular}

${ }^{*}$, and ${ }^{* * *}$ indicate significance at 0.05 and 0.001 probability levels.

The descriptive statistics showed that the averages decreased for $\beta$-glucan, Zinc, Selenium, and Manganese for single plant derived accessions when compared with their original bulk accessions, while slight increases were observed for Iron and Magnesium (Table 5). Some accessions derived from seeds of single plant have given higher maximum values than their respective bulk accessions as shown for Magnesium, Calcium, and Copper, while the opposite was observed for Zinc, Selenium, and Potassium contents.

Based on the scores of the first and second principal components of PCA considering all measured parameters, the wild bulked seed accessions clustered separately from the entries of cultivated barley (elite germplasm and cultivars) (Figure 1). These comparisons between the accessions of Hordeum spontaneum with entries of cultivated barley for each of the traits are highlighted by the plots of density distributions showing clear differences between the two groups for $\beta$-glucan, Zinc, and Sodium contents (Figure 2). For the cultivars and elite germplasm, the averages were lower for $\beta$-glucan and for Zinc and Sodium contents compared with the entries from the wild barley samples, but their contents for Magnesium and Calcium were higher (Table 5). For $\beta$-glucan, only the cultivar Chifaa had a maximum content of $7.81 \%$ followed by the elite lines BL $12(6.21 \%)$, BL $9(5.66 \%)$, and the cultivars ACSAD 176 (5.89\%) and Tamellalet (5.43\%) (Appendix B). For Iron content, four accessions had levels above $50 \mathrm{ppm}$, while 8 out of 36 breeding lines and released cultivars had levels ranging from $50.32 \mathrm{ppm}$ for Arabi Abiad to $56.35 \mathrm{ppm}$ for the cultivar Laanaceur. For Zinc, the cultivars Taffa and Azara had the highest contents of $46.92 \mathrm{ppm}$ and $46.53 \mathrm{ppm}$ respectively, exceeding any of the wild accessions. For Selenium, the cultivars Rabat 071 and Tissa showed the highest content of $0.45 \mathrm{ppm}$. 


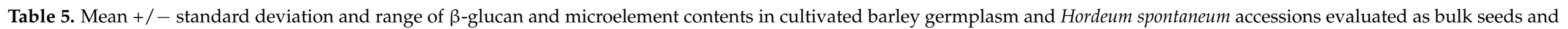
single plant seeds grown at Marchouch station during 2017_18 season.

\begin{tabular}{|c|c|c|c|c|c|c|c|c|c|}
\hline \multirow[b]{2}{*}{ Trait } & \multicolumn{3}{|c|}{ Mean } & \multicolumn{3}{|c|}{ Minimum } & \multicolumn{3}{|c|}{ Maximum } \\
\hline & Cultivated & Wild Bulk & $\begin{array}{l}\text { Wild Single } \\
\text { Plant (SP) }\end{array}$ & Cultivated & Wild Bulk & $\begin{array}{l}\text { Wild Single } \\
\text { Plant (SP) }\end{array}$ & Cultivated & Wild Bulk & $\begin{array}{l}\text { Wild Single } \\
\text { Plant (SP) }\end{array}$ \\
\hline$\beta$-glucan & $4.06 \pm 1.24$ & $6.51 \pm 1.53$ & $5.46 \pm 2.14$ & 1.62 & 1.44 & 0.85 & 7.81 & 11.31 & 11.14 \\
\hline Iron & $41.78 \pm 8.51$ & $34.06 \pm 9.41$ & $42.03 \pm 9.7$ & 28.26 & 18.08 & 19.2 & 56.72 & 58.7 & 58.14 \\
\hline Zinc & $28.74 \pm 9.18$ & $39.12 \pm 11.10$ & $35.94 \pm 5.04$ & 13.58 & 18.23 & 19.88 & 46.92 & 73.65 & 54.67 \\
\hline Selenium & $0.3 \pm 0.10$ & $0.31 \pm 0.11$ & $0.24 \pm 0.07$ & 0.09 & 0.16 & 0.08 & 0.45 & 0.53 & 0.46 \\
\hline Magnesium & $1717.0 \pm 274.8$ & $1570.0 \pm 174.0$ & $1618.7 \pm 272.3$ & 1369.1 & 1065.4 & 1018.8 & 2368.8 & 2074.0 & 2594.9 \\
\hline Manganese & $21.11 \pm 4.47$ & $26.78 \pm 3.21$ & $19.55 \pm 4.84$ & 15.19 & 20.42 & 12.92 & 30.72 & 33.54 & 33.06 \\
\hline Potassium & $1503.9 \pm 246.3$ & $1577.4 \pm 205.0$ & $1330.4 \pm 209.9$ & 1046.1 & 1086.2 & 932.7 & 2100.1 & 2267.2 & 2092.5 \\
\hline Sodium & $261.4 \pm 132.2$ & $5260 \pm 124.7$ & $315.4 \pm 178.1$ & 112.3 & 301.9 & 90.7 & 735.4 & 876.6 & 752.5 \\
\hline Calcium & $756.9 \pm 149.7$ & $667.3 \pm 74.7$ & $698.7 \pm 122.4$ & 459.3 & 472.0 & 428.0 & 1017.7 & 880.9 & 976.5 \\
\hline Copper & $20.51 \pm 5.79$ & $19.73 \pm 3.98$ & $19.06 \pm 4.43$ & 10.4 & 11.37 & 10.31 & 31.46 & 29.59 & 32.54 \\
\hline
\end{tabular}



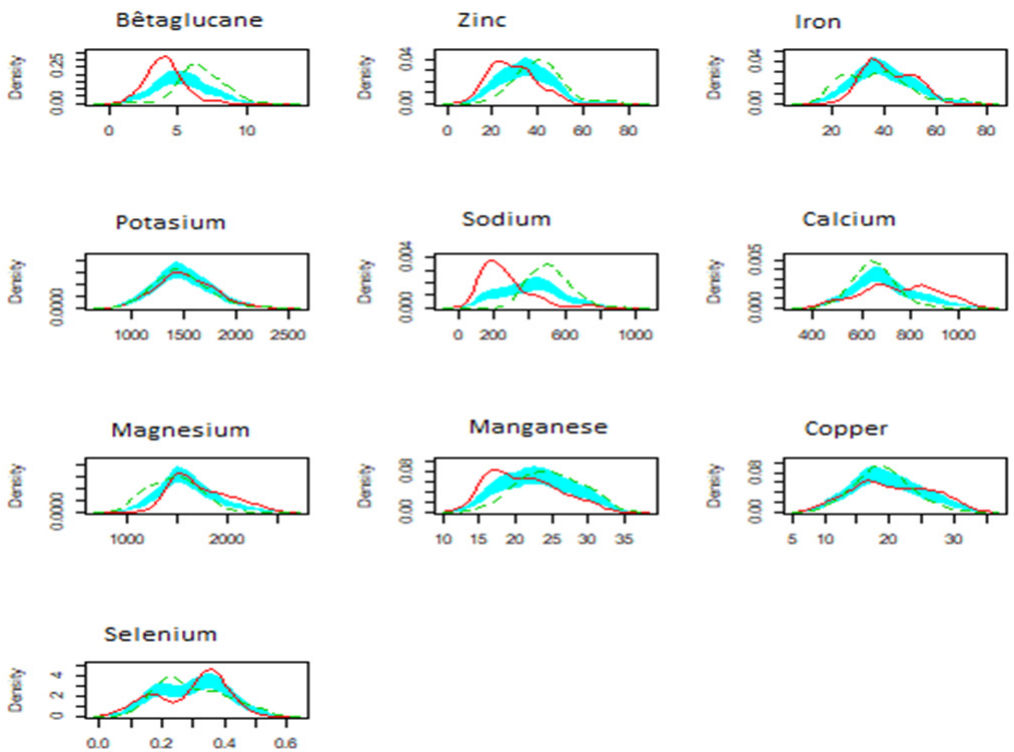

Figure 1. Density distribution for comparison of Hordeum spontaneum bulked seed accessions with elite germplasm and cultivars of cultivated barley for $\beta$-glucan and microelements contents.

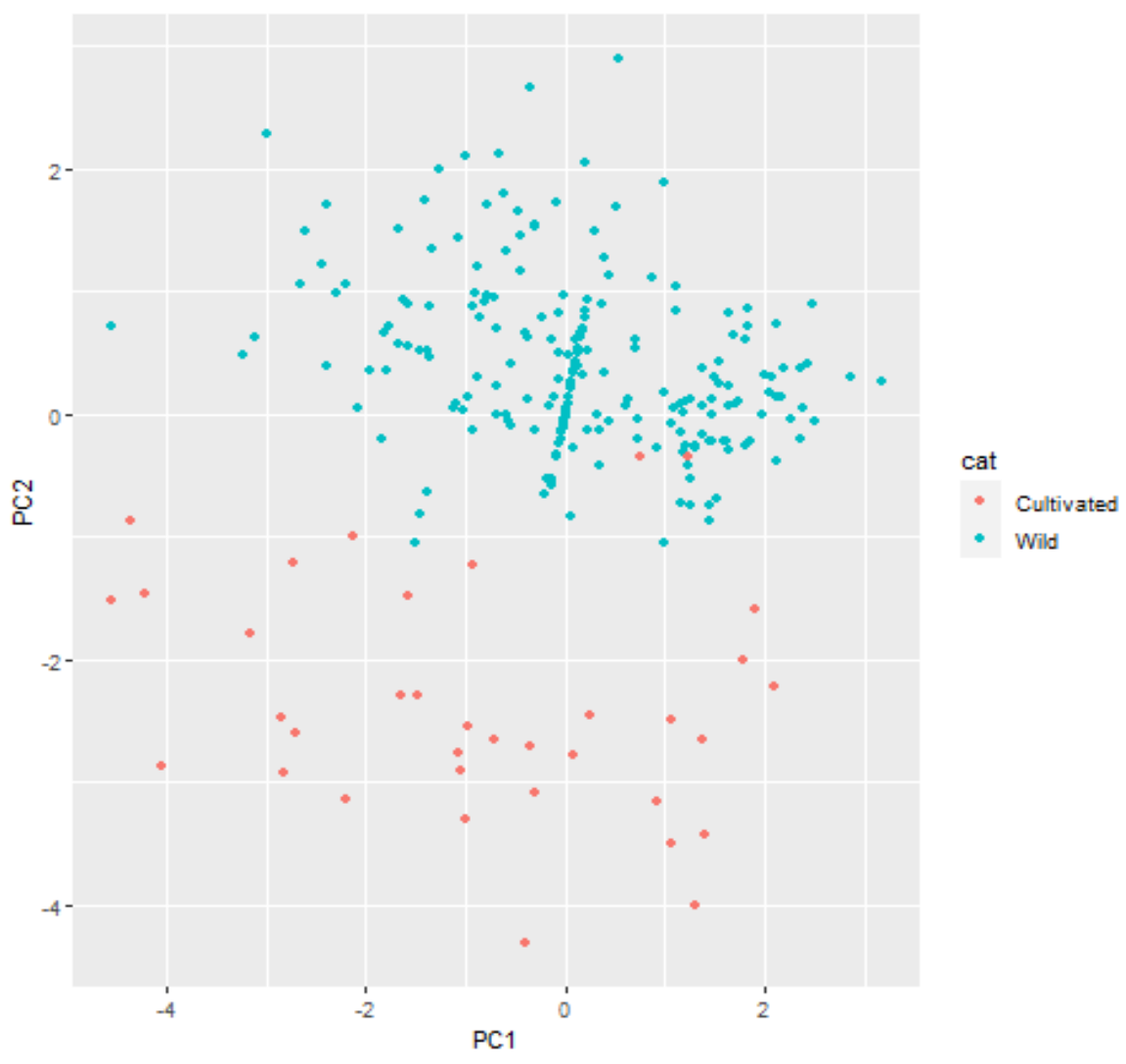

Figure 2. PCA analysis score plot on the first and second principal components (PC1 and PC2) for distribution of Hordeum spontaneum bulked seed accessions with elite germplasm and cultivars of cultivated barley based on $\beta$-glucan and microelements contents.

Based on the values of the wild accessions issued for single plants, several accessions that had higher values for $\beta$-glucan and microelements than the best cultivars and elite germplasm except for Calcium, Copper, and Manganese contents. For $\beta$-glucan, only three accessions had less than $5 \%$, and eighteen accessions had more than $8 \%$ including four 
accessions (IG 144997, IG 145604, IG 38679, and IG 38658) with content ranging from 10.05 to $10.37 \%$. For Zinc content, the accession IG 39859 had the highest content of $53.05 \mathrm{ppm}$. For Iron, eleven accessions showed contents of $56 \mathrm{ppm}$ and above but two accessions IG 39859 and 144913 had 61.14 and 66.4 ppm respectively. For Magnesium, five accessions had contents of 2400 ppm or more, with the highest content recorded at IG 145155. For Potassium, more than $50 \%$ of the accessions have contents of 2900 and above with highest values obtained at IG 39884 (3505.18 ppm) and IG 144997 (3590.18 ppm). For Selenium, four accessions have contents above 0.44 ppm with highest content obtained at IG 135624 (0.51 ppm).

\subsection{Correlations among Traits for Different Types of Germplasm}

Elite germplasm and cultivars showed he highest positive correlations between Magnesium, Manganese, and p(0.75 to 0.88) and between Selenium and Zinc (0.84), and the highest negative correlations between Iron and Selenium $(-0.85)$ and between Iron and Zinc (-0.85) (Table 6). $\beta$-glucan showed significant negative correlations only with Magnesium (-0.36) and Manganese (-0.34). Calcium and Copper were correlated with Manganese and Magnesium. However, in the wild accessions, these correlations changed and differed between the two types of wild accessions (Tables 7 and 8 ). $\beta$-glucan content was slightly correlated with Manganese (0.18) in the case of bulked seed accessions and with Sodium $(-0.21)$ in the case of single plant derived seed accessions. For the other microelements, the only consistent significant and positive correlations were found between Iron and Calcium and between Iron and Manganese for the two types of germplasm of wild Hordeum.

Table 6. Correlations among $\beta$-glucan and micronutrients contents of Hordeum spontaneum bulked seed accessions.

\begin{tabular}{|c|c|c|c|c|c|c|c|c|c|}
\hline & $\beta$-Glucan & Calcium & Copper & Iron & Magnesium & Manganese & Potassium & Selenium & Sodium \\
\hline \multicolumn{10}{|l|}{$\beta$-glucan } \\
\hline Calcium & -0.02 & & & & & & & & \\
\hline Copper & -0.05 & $0.28 * *$ & & & & & & & \\
\hline Iron & 0 & $0.20 *$ & 0.17 & & & & & & \\
\hline Magnesium & -0.07 & 0.13 & -0.17 & 0.02 & & & & & \\
\hline Manganese & 0.18 * & 0.13 & -0.03 & $0.22 *$ & 0.15 & & & & \\
\hline Potassium & 0.04 & 0.06 & $0.27^{* *}$ & $0.43^{* * * *}$ & $-0.38^{* * * *}$ & 0.1 & & & \\
\hline Selenium & -0.01 & $0.26^{* *}$ & 0.01 & 0.03 & 0.17 & -0.05 & $-0.19 *$ & & \\
\hline Sodium & 0 & $0.58^{* * * *}$ & $0.24^{* *}$ & 0.07 & $0.27^{* *}$ & $0.19^{*}$ & -0.1 & 0.06 & \\
\hline Zinc & -0.03 & -0.04 & -0.18 * & -0.04 & $0.31^{* * *}$ & $0.28 * *$ & $-0.23 *$ & 0.03 & 0.02 \\
\hline
\end{tabular}

Table 7. Correlations among $\beta$-glucan and micronutrients contents of Hordeum spontaneum of single plant seeds derived accessions.

\begin{tabular}{|c|c|c|c|c|c|c|c|c|c|}
\hline & $\beta$-Glucan & Calcium & Copper & Iron & Magnesium & Manganese & Potassium & Selenium & Sodium \\
\hline \multicolumn{10}{|l|}{$\beta$-glucan } \\
\hline Calcium & 0.04 & & & & & & & & \\
\hline Copper & 0.17 & -0.01 & & & & & & & \\
\hline Iron & 0.03 & $0.26^{* *}$ & $0.27^{* *}$ & & & & & & \\
\hline Magnesium & 0.13 & $0.22 *$ & $0.49^{* * * *}$ & $0.34^{* * *}$ & & & & & \\
\hline Manganese & 0.07 & 0.15 & $0.50 * * * *$ & $0.26^{* *}$ & $0.67 * * * *$ & & & & \\
\hline Potassium & 0.08 & 0.1 & 0.15 & 0.04 & $0.44^{* * * *}$ & $0.24^{* *}$ & & & \\
\hline Selenium & 0.03 & -0.02 & -0.1 & -0.02 & -0.05 & -0.16 & 0.03 & & \\
\hline Sodium & $-0.21 *$ & $-0.47^{* * * *}$ & 0.06 & $-0.20 *$ & -0.17 & -0.14 & 0.01 & -0.07 & \\
\hline Zinc & -0.08 & -0.16 & -0.18 & $-0.20 *$ & $-0.41^{* * * *}$ & $-0.28 * *$ & $-0.25^{* *}$ & $0.19 *$ & 0.08 \\
\hline
\end{tabular}

$*{ }^{* *}, * * *$ and ${ }^{* * *}$ indicate significance at $0.05,0.01,0.001$ and 0.0001 probability levels.

After identifying the accessions with the highest contents for each microelement, there are several accessions that combine high contents for two, three, and more measured traits. Table 9 shows the accessions derived from individual plants that have higher content than the averages for $\beta$-glucan and Iron, Zinc, and Selenium. 
Table 8. Correlations among $\beta$-glucan and micronutrients contents elite germplasm and cultivars of cultivated barley.

\begin{tabular}{|c|c|c|c|c|c|c|c|c|c|}
\hline & $\beta$-Glucan & Calcium & Copper & Iron & Magnesium & Manganese & Potassium & Selenium & Sodium \\
\hline \multicolumn{10}{|l|}{$\beta$-glucan } \\
\hline Calcium & -0.31 & & & & & & & & \\
\hline Copper & 0.03 & -0.15 & & & & & & & \\
\hline Iron & -0.06 & -0.07 & -0.12 & & & & & & \\
\hline Magnesium & $-0.36^{*}$ & $0.40 *$ & 0.38 * & 0.01 & & & & & \\
\hline Manganese & $-0.34 *$ & $0.51^{* *}$ & $0.39 *$ & -0.08 & $0.88^{* * * *}$ & & & & \\
\hline Potassium & -0.28 & $0.42 *$ & 0.26 & 0 & $0.80^{* * * *}$ & $0.75^{* * * *}$ & & & \\
\hline Selenium & 0.07 & 0.01 & 0.05 & $-0.85^{* * * *}$ & -0.19 & -0.08 & -0.15 & & \\
\hline Sodium & -0.19 & -0.05 & $0.52 * *$ & -0.02 & 0.14 & 0.3 & 0.18 & -0.07 & \\
\hline Zinc & 0.08 & -0.09 & 0.19 & $-0.85^{* * * *}$ & -0.04 & -0.02 & -0.04 & $0.84^{* * * *}$ & -0.05 \\
\hline
\end{tabular}

$*, * *$ and ${ }^{* * * *}$ indicate significance at $0.05,0.01$ and 0.0001 probability levels.

Table 9. Single plant accessions of Hordeum spontaneum with combined contents of $\beta$-glucan and microelements (Iron, Zinc, and Selenium) above the averages.

\begin{tabular}{|c|c|c|c|c|c|c|c|c|c|c|}
\hline Genotype & $\beta$-Glucan (\%) & $\begin{array}{c}\text { Calcium } \\
(\mathrm{ppm})\end{array}$ & $\begin{array}{l}\text { Copper } \\
\text { (ppm) }\end{array}$ & $\begin{array}{c}\text { Iron } \\
\text { (ppm) }\end{array}$ & $\begin{array}{l}\text { Magnesium } \\
\text { (ppm) }\end{array}$ & $\begin{array}{c}\text { Manganese } \\
\text { (ppm) }\end{array}$ & $\begin{array}{l}\text { Potassium } \\
\text { (ppm) }\end{array}$ & $\begin{array}{l}\text { Selenium } \\
\text { (ppm) }\end{array}$ & $\begin{array}{l}\text { Sodium } \\
\text { (ppm) }\end{array}$ & $\begin{array}{c}\text { Zinc } \\
(\mathrm{ppm})\end{array}$ \\
\hline 144,121 & 5.47 & 535.9 & 16.19 & 50.15 & 1635.18 & 17.1 & 2406.31 & 0.3 & 309.76 & 39.21 \\
\hline 144,911 & 8.08 & 549.06 & 17.13 & 56.34 & 1469 & 20.23 & 2828.52 & 0.3 & 342.75 & 30.29 \\
\hline 144,113 & 6.21 & 558.47 & 16.85 & 48.38 & 1742.61 & 17.3 & 3144.74 & 0.34 & 293.97 & 32.77 \\
\hline 145,508 & 6.57 & 560.72 & 13.98 & 49.95 & 1452.6 & 20.01 & 2993.7 & 0.39 & 293.76 & 33.19 \\
\hline 131,643 & 7.42 & 563.17 & 15.58 & 51.96 & 1686.06 & 18.43 & 2436.65 & 0.31 & 303.73 & 38.06 \\
\hline 144,124 & 9.44 & 576.44 & 16.98 & 52.7 & 1656.33 & 17.76 & 2668.47 & 0.34 & 355.84 & 32.27 \\
\hline 135,624 & 6.67 & 594.75 & 16.76 & 52.07 & 2639.28 & 23.16 & 1748.9 & 0.51 & 289.44 & 37.74 \\
\hline 40,104 & 5.64 & 596.97 & 16.3 & 50.41 & 1683.95 & 18.08 & 2501.08 & 0.29 & 333.75 & 35.42 \\
\hline 107,046 & 6.23 & 619.41 & 18.43 & 53.05 & 1648 & 21.55 & 3069.12 & 0.32 & 407.93 & 35.55 \\
\hline 39,940 & 6.1 & 655.15 & 15.04 & 52.44 & 1678.84 & 18.38 & 3081.61 & 0.32 & 370.55 & 32.98 \\
\hline 39859 & 7.67 & 674.37 & 18.94 & 61.14 & 2212.03 & 24.65 & 2816.08 & 0.33 & 561.14 & 53.05 \\
\hline
\end{tabular}

\section{Discussion}

ICARDA, in collaboration with many national agricultural research programs, is promoting the use of barley as food crop. Barley is not only adapted to harsh conditions, but also has the potential to improve both food and nutritional security, especially for poor communities living in drylands and mountainous regions. The genetic resources conserved in the genebanks are an important source of parental germplasm for barley breeding programs. More importantly, the progenitor species Hordeum spontaneum could provide novel benefical diversity for resistance to major diseases and insects, tolerance to abiotic stresses and improvement of end-use quality and nutritional value of cultivated barley. The result of the present study have confirmed the penitential of wild barley as a gene reservoir to improve $\beta$-glucan and micronutrient content. Most of the tested cultivars and elite germplasm had a low $\beta$-glucan content of less than $5 \%$, with a range from 1.62 to $7.81 \%$ Similar ranges of $\beta$-glucan content are also reported by [26] (2.2-8.4\%) and [27] $(4.03-7.57 \%)$ in panels of cultivated barley. The concentrations in other cereal crops varied between $2.2 \%$ to $7.8 \%$ in oat, $1.2 \%$ to $2.0 \%$ in rye, while the content in wheat did not exceed $1.4 \%$ [28]. A Large numbers of accessions derived either as bulk or as single plant seeds had of $\beta$-glucan content above $8 \%$ and can be used for breeding new barley cultivars that combine high nutritional value with potentially associated health benefits lowering blood cholesterol and glycemic index.

Refs. [14] and [19] have reported that more than 22 micronutrients are critical for various cellular and metabolic activities. However, special attention is paid to enhancing Iron, Zinc, and Selenium content in the diet worldwide (WHO, 2017). Among cereals, barley grain is the main source of $\mathrm{P}, \mathrm{Ca}, \mathrm{K}, \mathrm{Mg}, \mathrm{Na}, \mathrm{Cu}$, and $\mathrm{Zn}$, as well as of $\mathrm{Si}$, and our study showed a wide range of levels of these elements both in the germplasm of cultivated barley and in Hordeum spontaneum accessions. The ranges of contents of these key elements are comparable to those reported in other studies [29]. Higher ranges were found for Iron and Zinc contents in a set of wild barley [30] with respective values of 329.10 and 
493.9 ppm. Similarly, higher Iron content (7.73 to $109.60 \mathrm{ppm}$ ) was reported for landraces from Ethiopia and Eritrea [31]. In a previous study, the differences in mineral nutrient concentrations were attributed to environmental and growing conditions [32]. In another study, no significant differences were found between genotypes of cultivated barley and H. spontaneum accessions in terms of micronutrients, suggesting that the mineral nutrient quality of barley was not affected by the domestication process [33]. However, other studies have reported that in the process of domestication and breeding for yield, biotic and abiotic stress, barley has lost many desirable traits that need to be reintroduced by using the wild progenitor [33]. However, a high concentration of mineral elements in cereal grains does not mean that they are available to humans, as anti-nutrients, such phytate, phenolics, may limit their absorption. Grains also contain promoters, such as $\beta$ carotene, S-containing amino acids, etc., which enhance the bioavailability of minerals or decrease the activity of inhibitors [13].

Our study showed has shown that it is necessary to extract and evaluate single plants from the original accession to select those with high $\beta$-glucan and high micronutrient contents for use in pre-breeding and in genome wide association studies. ICARDA, with support for the Global Crop Diversity Trust, is strengthening pre-breeding efforts in barley through extensive use of Hordeum spontaneum accessions to enhance resistance to major diseases and tolerance to drought and heat, and to improve quality and nutritional attributes.

For the cultivated barley, high $\beta$-glucan content is associated with a locus on chromosome $2(2 \mathrm{H})$ as reported by [34].

One of the varieties released in Morocco, only the 'Chifaa' variety with hulless grains has a high $\beta$-glucan content, can be used as a biofortified variety and can be used as a recurrent parent for developing germplasm combining high $\beta$-glucan and high zinc, iron and selenium content.

\section{Conclusions}

Barley, besides its multiple uses and adaptation to harsh conditions, has the potential to improve food and nutrition security, especially for poor rural communities. The wild progenitor Hordeum spontaneum had accessions high in $\beta$-glucan and high in Zinc, Iron, and Selenium, demonstrating the need to increase pre-breeding efforts to develop biofortified barley germplasm.

Author Contributions: Conceptualization and methodology, A.A., M.I. and F.E. Field trial establishment and data collecting, F.E. and A.J. Laboratory analysis: F.E., A.E.-b. and G.S. Statistical analysis, Z.K., F.E. and A.A. Writing—original draft preparation, F.E. and A.A. Writing-review and editing, B.K., M.I., A.J. and Z.K. All authors have read and agreed to the published version of the manuscript.

Funding: This work was undertaken as part of the initiative "Adapting Agriculture to Climate Change: Collecting, Protecting and Preparing Crop Wild Relatives", which is supported by the Government of Norway and managed by the Global Crop Diversity Trust (https: / / www.cwrdiversity. org/project/pre-breeding/, accessed on 23 September 2021). We are very grateful to the financial support of GIZ (Deutsche Gesellschaft für Internationale Zusammenarbeit) through the attributed funding provided to ICARDA genebank.

Data Availability Statement: All data are available at ICARDA genebank database.

Acknowledgments: We would like to thank Adil Moulakat and Hafid Aberkane for their help with field activities and Miguel Sanchez-Garcia for providing access to ICARDA quality laboratory.

Conflicts of Interest: The authors declare no conflict of interest. 


\section{Appendix A}

Table A1. BLUEs for Hordeum spontaneum accessions bulk seeds for $\beta$-glucan microelements contents.

\begin{tabular}{|c|c|c|c|c|c|c|c|c|c|c|}
\hline Genotype & $\begin{array}{c}\beta-\text { Glucan } \\
(\%)\end{array}$ & $\begin{array}{l}\text { Calcium } \\
\text { (ppm) }\end{array}$ & $\begin{array}{l}\text { Copper } \\
\text { (ppm) }\end{array}$ & $\begin{array}{c}\text { Iron } \\
\text { (ppm) }\end{array}$ & $\begin{array}{l}\text { Magnesium } \\
\text { (ppm) }\end{array}$ & $\begin{array}{c}\text { Manganese } \\
\quad(\mathrm{ppm})\end{array}$ & $\begin{array}{l}\text { Potassium } \\
\text { (ppm) }\end{array}$ & $\begin{array}{l}\text { Selenium } \\
\text { (ppm) }\end{array}$ & $\begin{array}{l}\text { Sodium } \\
\text { (ppm) }\end{array}$ & $\begin{array}{c}\text { Zinc } \\
(\mathrm{ppm})\end{array}$ \\
\hline 38611 & 7.44 & 551.79 & 17.70 & 55.43 & 1519.17 & 21.08 & 2501.85 & 0.24 & 279.19 & 24.52 \\
\hline 38615 & 7.92 & 570.13 & 15.76 & 43.92 & 1639.26 & 21.31 & 2871.50 & 0.22 & 352.84 & 36.40 \\
\hline 38617 & 6.44 & 591.60 & 17.54 & 42.41 & 1447.31 & 20.53 & 2836.92 & 0.32 & 391.04 & 29.27 \\
\hline 38656 & 8.64 & 580.77 & 16.44 & 52.28 & 1718.83 & 18.26 & 2572.36 & 0.27 & 358.48 & 33.24 \\
\hline 38658 & 10.05 & 593.32 & 19.73 & 45.40 & 1717.17 & 17.82 & 2584.57 & 0.23 & 522.70 & 33.18 \\
\hline 38660 & 7.09 & 572.03 & 15.77 & 42.24 & 1595.94 & 17.79 & 2531.20 & 0.22 & 448.40 & 29.20 \\
\hline 38673 & 8.86 & 578.46 & 13.28 & 41.51 & 1620.73 & 16.63 & 2953.62 & 0.35 & 418.43 & 24.61 \\
\hline 38679 & 10.35 & 565.74 & 18.41 & 51.07 & 1665.99 & 19.65 & 2452.36 & 0.28 & 440.40 & 20.70 \\
\hline 38682 & 7.50 & 561.42 & 14.95 & 41.82 & 1585.27 & 17.70 & 2747.25 & 0.28 & 302.77 & 25.35 \\
\hline 38693 & 7.95 & 667.03 & 16.54 & 50.77 & 1426.18 & 19.32 & 2538.62 & 0.27 & 479.69 & 18.13 \\
\hline 38780 & 7.76 & 585.66 & 15.88 & 41.50 & 1193.63 & 21.18 & 1001.17 & 0.34 & 350.45 & 35.21 \\
\hline 38814 & 9.78 & 525.31 & 16.42 & 42.59 & 1645.32 & 19.71 & 2487.10 & 0.26 & 368.51 & 30.65 \\
\hline 38821 & 6.93 & 481.66 & 17.68 & 49.59 & 1557.37 & 17.20 & 2633.09 & 0.26 & 240.16 & 29.69 \\
\hline 38822 & 6.88 & 517.85 & 16.28 & 52.21 & 1451.44 & 18.50 & 3091.46 & 0.23 & 333.22 & 30.83 \\
\hline 38826 & 6.51 & 535.93 & 17.12 & 57.63 & 1678.43 & 19.52 & 2371.31 & 0.22 & 332.81 & 35.77 \\
\hline 38827 & 6.16 & 527.94 & 11.32 & 51.08 & 1644.52 & 15.93 & 2435.99 & 0.21 & 294.38 & 34.65 \\
\hline 38931 & 6.19 & 557.64 & 17.25 & 49.88 & 1523.77 & 17.61 & 2827.57 & 0.22 & 306.04 & 26.80 \\
\hline 38943 & 9.53 & 574.53 & 17.74 & 51.74 & 1656.38 & 18.01 & 2436.76 & 0.22 & 392.49 & 28.27 \\
\hline 39002 & 7.07 & 556.79 & 14.58 & 52.00 & 1533.23 & 23.98 & 2304.69 & 0.20 & 434.96 & 34.67 \\
\hline 39127 & 8.04 & 514.01 & 15.23 & 50.95 & 1714.51 & 18.79 & 2409.51 & 0.27 & 272.11 & 36.32 \\
\hline 39565 & 5.72 & 612.26 & 16.31 & 43.39 & 1508.72 & 21.28 & 2602.45 & 0.30 & 411.17 & 23.76 \\
\hline 39733 & 9.06 & 525.88 & 16.30 & 46.85 & 1619.55 & 21.79 & 2737.87 & 0.23 & 275.48 & 30.66 \\
\hline 39852 & 5.63 & 648.90 & 17.16 & 54.41 & 1640.59 & 20.97 & 3062.92 & 0.36 & 408.52 & 28.90 \\
\hline 39859 & 7.67 & 674.37 & 18.94 & 61.14 & 2212.03 & 24.65 & 2816.08 & 0.33 & 561.14 & 53.05 \\
\hline 39880 & 7.30 & 594.39 & 20.97 & 53.10 & 1519.04 & 20.97 & 2713.88 & 0.22 & 337.69 & 30.38 \\
\hline 39884 & 6.57 & 533.01 & 17.44 & 54.70 & 2633.68 & 24.67 & 3505.18 & 0.17 & 479.40 & 37.40 \\
\hline 39885 & 8.98 & 531.22 & 16.38 & 39.69 & 1529.87 & 17.61 & 2872.09 & 0.31 & 323.68 & 22.97 \\
\hline 39891 & 5.80 & 521.03 & 17.32 & 47.70 & 1335.13 & 17.32 & 2506.06 & 0.21 & 325.00 & 25.53 \\
\hline 39933 & 6.37 & 465.48 & 22.89 & 41.05 & 1851.43 & 12.85 & 2403.10 & 0.21 & 235.07 & 17.56 \\
\hline 39934 & 7.27 & 742.54 & 19.07 & 56.80 & 1795.44 & 21.07 & 2826.03 & 0.21 & 495.78 & 31.54 \\
\hline 39935 & 5.94 & 572.99 & 17.74 & 49.78 & 1628.14 & 21.16 & 2627.32 & 0.24 & 419.69 & 35.17 \\
\hline 39936 & 6.94 & 592.82 & 19.27 & 48.02 & 1644.61 & 16.88 & 2707.20 & 0.37 & 400.63 & 26.02 \\
\hline 39939 & 7.37 & 515.26 & 16.63 & 46.69 & 1666.12 & 17.31 & 2335.22 & 0.26 & 334.12 & 31.98 \\
\hline 39940 & 6.10 & 655.15 & 15.04 & 52.44 & 1678.84 & 18.38 & 3081.61 & 0.32 & 370.55 & 32.98 \\
\hline 39961 & 6.55 & 527.99 & 16.37 & 43.09 & 1591.81 & 16.80 & 2288.94 & 0.25 & 306.26 & 37.22 \\
\hline 39962 & 6.35 & 588.25 & 17.21 & 58.67 & 1506.71 & 20.82 & 2702.66 & 0.37 & 357.23 & 28.45 \\
\hline 40009 & 6.15 & 549.41 & 14.27 & 44.71 & 1420.46 & 20.00 & 2398.27 & 0.24 & 421.14 & 22.65 \\
\hline 40043 & 6.30 & 539.41 & 16.40 & 55.08 & 1782.98 & 19.11 & 2969.73 & 0.26 & 284.37 & 31.99 \\
\hline 40056 & 7.14 & 547.15 & 15.79 & 41.51 & 1635.39 & 17.10 & 2661.53 & 0.25 & 307.97 & 31.90 \\
\hline 40082 & 6.80 & 563.74 & 17.63 & 44.41 & 1559.64 & 18.95 & 2774.27 & 0.23 & 275.04 & 19.63 \\
\hline 40095 & 7.68 & 529.53 & 17.10 & 56.30 & 1615.28 & 17.53 & 2425.60 & 0.26 & 334.66 & 38.56 \\
\hline 40104 & 5.64 & 596.97 & 16.30 & 50.41 & 1683.95 & 18.08 & 2501.08 & 0.29 & 333.75 & 35.42 \\
\hline 40107 & 7.24 & 608.17 & 19.85 & 56.46 & 1805.71 & 17.63 & 2701.08 & 0.45 & 446.71 & 26.40 \\
\hline 40125 & 7.42 & 598.85 & 19.08 & 39.37 & 1633.73 & 18.02 & 2622.96 & 0.27 & 493.21 & 29.01 \\
\hline 40143 & 6.95 & 628.04 & 17.79 & 44.83 & 2247.98 & 19.76 & 1722.68 & 0.35 & 466.88 & 31.75 \\
\hline 40184 & 6.37 & 561.21 & 15.26 & 39.83 & 1486.25 & 15.49 & 2622.97 & 0.27 & 428.34 & 25.63 \\
\hline 40195 & 6.66 & 586.80 & 17.45 & 47.28 & 1578.22 & 16.36 & 2577.50 & 0.34 & 346.82 & 26.96 \\
\hline 107046 & 6.23 & 619.41 & 18.43 & 53.05 & 1648.00 & 21.55 & 3069.12 & 0.32 & 407.93 & 35.55 \\
\hline 10723 & 6.77 & 519.10 & 18.88 & 52.47 & 1580.64 & 16.99 & 2354.85 & 0.18 & 393.32 & 23.66 \\
\hline 107426 & 9.05 & 572.81 & 15.77 & 50.40 & 1396.51 & 17.05 & 2377.04 & 0.25 & 347.30 & 23.10 \\
\hline 116005 & 9.44 & 486.80 & 15.43 & 46.63 & 1587.59 & 19.90 & 2587.55 & 0.33 & 350.28 & 41.85 \\
\hline 116104 & 7.38 & 618.29 & 20.02 & 56.47 & 1716.45 & 17.76 & 2576.18 & 0.32 & 371.66 & 18.25 \\
\hline 120799 & 6.12 & 583.61 & 20.90 & 53.63 & 1749.66 & 18.72 & 2840.26 & 0.34 & 353.93 & 27.71 \\
\hline 126933 & 5.71 & 535.75 & 19.24 & 40.30 & 1600.09 & 18.39 & 2990.19 & 0.23 & 404.27 & 24.32 \\
\hline 129152 & 7.96 & 668.01 & 20.30 & 48.32 & 1719.95 & 18.43 & 3082.69 & 0.47 & 522.88 & 28.02 \\
\hline 131317 & 8.31 & 535.76 & 17.04 & 39.19 & 2377.53 & 21.58 & 1369.36 & 0.40 & 433.09 & 36.91 \\
\hline 131620 & 8.59 & 522.46 & 15.05 & 55.70 & 1572.04 & 17.13 & 2545.33 & 0.22 & 264.48 & 44.95 \\
\hline 131642 & 7.95 & 506.37 & 16.36 & 46.46 & 1504.62 & 17.82 & 2986.85 & 0.28 & 292.12 & 27.74 \\
\hline 131643 & 7.42 & 563.17 & 15.58 & 51.96 & 1686.06 & 18.43 & 2436.65 & 0.31 & 303.73 & 38.06 \\
\hline
\end{tabular}


Table A1. Cont.

\begin{tabular}{|c|c|c|c|c|c|c|c|c|c|c|}
\hline Genotype & $\begin{array}{c}\beta-\text {-Glucan } \\
(\%)\end{array}$ & $\begin{array}{l}\text { Calcium } \\
\text { (ppm) }\end{array}$ & $\begin{array}{l}\text { Copper } \\
\text { (ppm) }\end{array}$ & $\begin{array}{c}\text { Iron } \\
(\mathrm{ppm})\end{array}$ & $\begin{array}{l}\text { Magnesium } \\
\quad(\mathrm{ppm})\end{array}$ & $\begin{array}{c}\text { Manganese } \\
(\mathrm{ppm})\end{array}$ & $\begin{array}{l}\text { Potassium } \\
\text { (ppm) }\end{array}$ & $\begin{array}{l}\text { Selenium } \\
\text { (ppm) }\end{array}$ & $\begin{array}{l}\text { Sodium } \\
\text { (ppm) }\end{array}$ & $\begin{array}{c}\text { Zinc } \\
(\mathrm{ppm})\end{array}$ \\
\hline 131790 & 7.11 & 522.10 & 15.55 & 37.20 & 1377.76 & 18.12 & 2236.12 & 0.24 & 360.09 & 24.40 \\
\hline 132489 & 5.98 & 527.05 & 16.83 & 54.86 & 1614.35 & 19.50 & 2436.93 & 0.25 & 329.26 & 38.68 \\
\hline 135349 & 6.99 & 541.23 & 14.98 & 43.41 & 1545.15 & 20.62 & 3009.04 & 0.24 & 328.95 & 32.61 \\
\hline 135624 & 6.67 & 594.75 & 16.76 & 52.07 & 2639.28 & 23.16 & 1748.90 & 0.51 & 289.44 & 37.74 \\
\hline 135854 & 5.62 & 555.77 & 19.69 & 44.19 & 1731.39 & 19.52 & 3008.38 & 0.33 & 314.99 & 38.55 \\
\hline 139618 & 6.86 & 562.66 & 17.41 & 44.83 & 1664.68 & 17.98 & 3032.21 & 0.41 & 263.88 & 28.01 \\
\hline 140149 & 5.84 & 568.34 & 19.63 & 54.81 & 1678.48 & 18.46 & 3097.11 & 0.34 & 342.42 & 20.67 \\
\hline 140552 & 6.64 & 551.18 & 16.79 & 45.04 & 2191.39 & 21.72 & 1960.93 & 0.31 & 430.05 & 33.84 \\
\hline 142356 & 5.24 & 506.65 & 12.61 & 49.78 & 1405.29 & 15.40 & 2679.43 & 0.33 & 316.64 & 25.89 \\
\hline 142486 & 6.19 & 552.48 & 16.42 & 40.68 & 1533.07 & 21.28 & 2646.54 & 0.22 & 415.51 & 31.23 \\
\hline 144112 & 6.85 & 521.54 & 15.96 & 53.02 & 1542.57 & 20.02 & 2291.94 & 0.24 & 328.19 & 28.48 \\
\hline 144113 & 6.21 & 558.47 & 16.85 & 48.38 & 1742.61 & 17.30 & 3144.74 & 0.34 & 293.97 & 32.77 \\
\hline 144114 & 6.38 & 481.97 & 20.67 & 51.38 & 1494.32 & 19.35 & 2871.33 & 0.35 & 277.43 & 26.88 \\
\hline 144116 & 1.85 & 546.42 & 14.43 & 31.92 & 1505.78 & 17.32 & 2450.73 & 0.31 & 271.35 & 32.69 \\
\hline 144117 & 5.99 & 561.23 & 13.71 & 37.48 & 1966.47 & 21.64 & 610.25 & 0.34 & 463.46 & 46.93 \\
\hline 144119 & 6.61 & 522.84 & 14.02 & 46.92 & 1631.24 & 16.75 & 2293.05 & 0.26 & 356.86 & 31.59 \\
\hline 144120 & 6.55 & 557.18 & 17.69 & 53.10 & 1429.95 & 17.49 & 2830.13 & 0.26 & 410.78 & 25.17 \\
\hline 144121 & 5.47 & 535.90 & 16.19 & 50.15 & 1635.18 & 17.10 & 2406.31 & 0.30 & 309.76 & 39.21 \\
\hline 144123 & 6.35 & 591.38 & 16.72 & 43.24 & 1754.84 & 17.15 & 2883.60 & 0.22 & 412.34 & 33.95 \\
\hline 144124 & 9.44 & 576.44 & 16.98 & 52.70 & 1656.33 & 17.76 & 2668.47 & 0.34 & 355.84 & 32.27 \\
\hline 144126 & 5.64 & 550.13 & 16.79 & 43.63 & 1595.70 & 19.34 & 2409.99 & 0.34 & 360.28 & 30.32 \\
\hline 144127 & 5.88 & 534.01 & 18.45 & 51.25 & 1535.54 & 21.33 & 2903.24 & 0.21 & 348.01 & 25.19 \\
\hline 144128 & 5.52 & 546.27 & 14.94 & 49.70 & 1626.51 & 17.86 & 2552.50 & 0.32 & 378.66 & 24.70 \\
\hline 144129 & 6.24 & 612.60 & 21.50 & 38.42 & 1510.93 & 19.16 & 2503.19 & 0.20 & 344.01 & 22.23 \\
\hline 144157 & 6.13 & 571.11 & 16.07 & 49.11 & 1435.19 & 18.44 & 2548.19 & 0.37 & 380.16 & 20.37 \\
\hline 144161 & 6.74 & 560.23 & 17.59 & 53.62 & 1566.68 & 14.76 & 3040.18 & 0.24 & 296.69 & 31.64 \\
\hline 144170 & 7.11 & 563.21 & 21.05 & 39.14 & 1736.76 & 18.59 & 2895.07 & 0.23 & 412.48 & 33.45 \\
\hline 144898 & 7.56 & 582.42 & 18.65 & 43.07 & 1628.11 & 17.41 & 2502.29 & 0.25 & 389.05 & 30.73 \\
\hline 144903 & 9.28 & 588.83 & 19.57 & 45.55 & 1667.80 & 21.59 & 2950.65 & 0.21 & 363.19 & 32.63 \\
\hline 144911 & 8.08 & 549.06 & 17.13 & 56.34 & 1469.00 & 20.23 & 2828.52 & 0.30 & 342.75 & 30.29 \\
\hline 144913 & 2.39 & 639.68 & 22.33 & 66.40 & 1827.50 & 13.51 & 2501.61 & 0.41 & 608.07 & 23.32 \\
\hline 144927 & 6.09 & 668.08 & 21.58 & 49.99 & 1883.94 & 16.30 & 2944.46 & 0.25 & 521.12 & 26.78 \\
\hline 144930 & 6.67 & 524.37 & 13.93 & 39.40 & 1654.25 & 19.96 & 2419.55 & 0.24 & 390.81 & 33.80 \\
\hline 144933 & 6.94 & 498.09 & 16.40 & 36.95 & 1579.88 & 18.64 & 2724.99 & 0.22 & 268.71 & 31.72 \\
\hline 144951 & 6.12 & 556.03 & 17.33 & 49.52 & 1659.32 & 19.67 & 2682.05 & 0.20 & 386.84 & 26.70 \\
\hline 144983 & 6.82 & 587.70 & 19.01 & 47.86 & 1630.39 & 20.58 & 2484.27 & 0.23 & 432.26 & 33.33 \\
\hline 144997 & 10.37 & 562.40 & 15.20 & 44.42 & 1374.40 & 19.91 & 3590.18 & 0.25 & 334.17 & 26.62 \\
\hline 145080 & 5.32 & 582.94 & 16.33 & 56.71 & 1730.91 & 16.43 & 2888.94 & 0.25 & 330.98 & 28.88 \\
\hline 145086 & 6.35 & 486.88 & 17.94 & 49.29 & 1477.66 & 18.65 & 2414.72 & 0.25 & 273.22 & 29.07 \\
\hline 145088 & 6.10 & 526.32 & 18.01 & 49.08 & 1538.11 & 17.50 & 2811.66 & 0.23 & 426.27 & 26.15 \\
\hline 145155 & 6.34 & 568.79 & 8.17 & 53.00 & 3425.85 & 18.31 & 1603.00 & 0.27 & 293.67 & 32.81 \\
\hline 145494 & 6.83 & 553.14 & 17.09 & 46.76 & 1538.03 & 17.33 & 2404.06 & 0.24 & 286.89 & 29.10 \\
\hline 145498 & 6.09 & 544.72 & 14.03 & 51.56 & 2576.05 & 19.60 & 1531.31 & 0.35 & 445.62 & 28.05 \\
\hline 145502 & 7.48 & 528.06 & 16.03 & 52.50 & 1536.66 & 18.56 & 2927.49 & 0.37 & 250.95 & 27.39 \\
\hline 145504 & 4.50 & 533.44 & 19.05 & 41.39 & 1716.64 & 18.20 & 2875.32 & 0.28 & 333.18 & 46.66 \\
\hline 145508 & 6.57 & 560.72 & 13.98 & 49.95 & 1452.60 & 20.01 & 2993.70 & 0.39 & 293.76 & 33.19 \\
\hline 145523 & 7.28 & 602.45 & 15.61 & 25.54 & 2012.87 & 13.85 & 487.09 & 0.46 & 343.45 & 34.70 \\
\hline 145528 & 6.98 & 576.51 & 17.04 & 56.32 & 1609.45 & 20.61 & 2484.83 & 0.19 & 396.50 & 24.79 \\
\hline 145535 & 7.23 & 564.42 & 14.42 & 40.65 & 2396.43 & 19.53 & 1797.04 & 0.27 & 457.17 & 28.32 \\
\hline 145539 & 6.64 & 553.22 & 14.60 & 51.55 & 1686.28 & 20.96 & 3083.44 & 0.20 & 334.40 & 26.34 \\
\hline 145555 & 5.65 & 550.05 & 15.37 & 39.04 & 1578.22 & 15.93 & 2382.82 & 0.22 & 309.20 & 30.40 \\
\hline 145556 & 5.41 & 509.62 & 14.28 & 42.72 & 2482.79 & 18.57 & 2074.17 & 0.18 & 473.68 & 36.29 \\
\hline 145575 & 7.47 & 602.31 & 16.10 & 48.01 & 1743.83 & 18.84 & 2913.77 & 0.29 & 371.13 & 21.56 \\
\hline 145597 & 7.38 & 562.11 & 16.52 & 32.83 & 1934.01 & 16.13 & 1072.27 & 0.37 & 377.43 & 35.84 \\
\hline 145602 & 6.46 & 556.04 & 15.91 & 24.40 & 1984.59 & 14.65 & 625.88 & 0.25 & 399.66 & 31.60 \\
\hline 145604 & 10.32 & 513.36 & 14.45 & 52.71 & 1715.64 & 21.12 & 2683.20 & 0.38 & 396.68 & 24.31 \\
\hline 145610 & 8.15 & 588.76 & 14.85 & 46.97 & 1595.10 & 16.00 & 2820.77 & 0.37 & 346.87 & 27.11 \\
\hline 146811 & 7.52 & 517.82 & 15.55 & 43.06 & 1375.27 & 20.22 & 2501.07 & 0.35 & 265.22 & 26.54 \\
\hline
\end{tabular}




\section{Appendix B}

Table A2. BLUEs for elite germplasm and v cultivated barley for $\beta$-glucan microelements contents.

\begin{tabular}{|c|c|c|c|c|c|c|c|c|c|c|}
\hline Genotype & $\beta$-Glucan & Calcium & Copper & Iron & Magnesium & Manganese & Potassium & Selenium & Sodium & Zinc \\
\hline Acsad 176 & 5.86 & 1017.69 & 12.10 & 43.16 & 1555.22 & 22.31 & 1535.28 & 0.31 & 197.36 & 25.02 \\
\hline Acsad 60 & 4.18 & 663.35 & 16.47 & 56.72 & 1456.14 & 17.54 & 1387.09 & 0.17 & 112.34 & 21.61 \\
\hline Acsad 68 & 3.40 & 808.98 & 23.69 & 33.34 & 1567.54 & 18.04 & 1459.75 & 0.37 & 208.67 & 36.85 \\
\hline Adrar & 4.55 & 681.01 & 23.82 & 39.26 & 1591.61 & 15.86 & 1427.87 & 0.34 & 146.61 & 31.25 \\
\hline Aglou & 3.37 & 771.17 & 16.51 & 46.54 & 1511.37 & 21.58 & 1503.01 & 0.31 & 163.70 & 24.25 \\
\hline Amalou & 1.62 & 932.21 & 26.01 & 54.70 & 2115.82 & 26.91 & 1773.44 & 0.11 & 459.45 & 13.79 \\
\hline Amira & 2.64 & 584.69 & 17.82 & 49.28 & 2281.37 & 27.75 & 2100.12 & 0.17 & 370.02 & 18.51 \\
\hline Arabi abiad & 3.37 & 727.65 & 10.87 & 50.32 & 1459.17 & 15.80 & 1338.77 & 0.12 & 173.20 & 15.63 \\
\hline $\begin{array}{c}\text { Arabi } \\
\text { aswad }\end{array}$ & 4.20 & 697.85 & 16.25 & 37.29 & 1423.67 & 15.19 & 1203.54 & 0.39 & 229.83 & 34.59 \\
\hline Arig8 & 5.00 & 720.85 & 15.92 & 35.19 & 1544.96 & 18.13 & 1439.19 & 0.35 & 230.83 & 23.52 \\
\hline Arta & 3.71 & 841.28 & 26.08 & 52.73 & 1796.40 & 20.66 & 1693.51 & 0.29 & 227.79 & 22.29 \\
\hline Assya & 4.71 & 719.28 & 31.46 & 48.48 & 2368.78 & 30.72 & 1782.98 & 0.17 & 279.83 & 19.93 \\
\hline Azara & 3.22 & 841.80 & 30.25 & 28.26 & 2162.29 & 29.36 & 1876.16 & 0.37 & 304.29 & 46.53 \\
\hline Azilal & 4.88 & 590.09 & 17.12 & 37.32 & 1369.12 & 16.49 & 1104.32 & 0.35 & 191.60 & 34.26 \\
\hline BL12 & 6.21 & 620.78 & 19.84 & 33.79 & 1439.64 & 15.83 & 1103.98 & 0.37 & 142.39 & 36.76 \\
\hline BL3 & 4.02 & 630.83 & 16.35 & 41.81 & 1588.32 & 17.07 & 1315.31 & 0.32 & 116.49 & 25.65 \\
\hline BL9 & 5.66 & 497.22 & 28.01 & 31.31 & 1393.35 & 15.78 & 1332.83 & 0.39 & 410.44 & 45.77 \\
\hline Chifaa & 7.81 & 488.31 & 28.29 & 53.49 & 1421.51 & 16.84 & 1550.22 & 0.18 & 517.51 & 21.78 \\
\hline Dophira & 1.70 & 877.83 & 26.48 & 39.57 & 1539.66 & 21.06 & 1393.13 & 0.34 & 735.40 & 26.82 \\
\hline Firdaws & 4.52 & 839.45 & 21.80 & 36.44 & 1566.21 & 22.66 & 1662.74 & 0.42 & 133.24 & 34.66 \\
\hline G1 & 3.19 & 688.59 & 25.51 & 34.79 & 1621.31 & 25.52 & 1314.40 & 0.34 & 433.24 & 26.75 \\
\hline G4 & 2.88 & 868.24 & 17.88 & 38.29 & 1742.08 & 21.29 & 1399.99 & 0.34 & 228.51 & 33.37 \\
\hline Laanaceur & 2.44 & 843.00 & 12.08 & 56.35 & 1678.35 & 17.80 & 1572.12 & 0.18 & 155.16 & 21.70 \\
\hline Massine & 2.93 & 1005.22 & 15.98 & 33.91 & 1884.29 & 24.48 & 1679.52 & 0.36 & 277.07 & 34.18 \\
\hline Merzaga & 4.13 & 668.51 & 10.40 & 53.32 & 1528.47 & 17.34 & 1336.68 & 0.18 & 167.40 & 21.20 \\
\hline Oussama & 4.73 & 961.57 & 16.02 & 34.58 & 1753.05 & 22.93 & 1514.38 & 0.36 & 255.68 & 32.27 \\
\hline Rabat071 & 3.63 & 983.18 & 20.26 & 35.38 & 2154.42 & 29.79 & 1952.11 & 0.45 & 331.57 & 36.32 \\
\hline Sen & 3.99 & 459.31 & 23.19 & 48.89 & 1415.06 & 18.44 & 1046.15 & 0.29 & 433.10 & 24.11 \\
\hline Sextin & 3.91 & 923.73 & 20.04 & 45.95 & 1925.30 & 24.22 & 1791.08 & 0.09 & 286.61 & 13.58 \\
\hline Taffa & 2.97 & 562.65 & 28.31 & 32.32 & 2019.34 & 23.32 & 1797.78 & 0.38 & 294.49 & 46.92 \\
\hline Tamellalet & 5.43 & 892.32 & 28.29 & 49.42 & 1963.20 & 24.18 & 1610.15 & 0.17 & 249.13 & 18.16 \\
\hline Tiddas & 4.65 & 795.94 & 15.75 & 34.78 & 1798.43 & 20.69 & 1560.14 & 0.35 & 175.75 & 29.48 \\
\hline Tissa & 3.38 & 669.06 & 21.45 & 36.16 & 1725.02 & 18.57 & 1432.83 & 0.45 & 139.72 & 35.88 \\
\hline UNA & 4.06 & 812.19 & 23.19 & 53.26 & 1927.27 & 22.70 & 1163.90 & 0.21 & 161.13 & 21.94 \\
\hline Vmoralis & 4.41 & 884.11 & 20.95 & 30.49 & 1995.69 & 26.50 & 1652.85 & 0.39 & 289.59 & 44.83 \\
\hline Zanbaka & 4.78 & 679.75 & 13.89 & 37.31 & 1528.25 & 16.76 & 1334.96 & 0.37 & 180.19 & 34.43 \\
\hline
\end{tabular}

\section{References}

1. Mayer, J.E.; Pfeiffer, W.H.; Beyer, P. Biofortified crops to alleviate micronutrient malnutrition. Curr. Opin. Plant Biol. 2008, 11, 166-170. [CrossRef] [PubMed]

2. Badr, A.; Rabey, H.E.; Effgen, S.; Ibrahim, H.H.; Pozzi, C.; Rohde, W.; Salamini, F. On the origin and domestication history of barley (Hordeum vulgare). Mol. Biol. Evol. 2000, 17, 499-510. [CrossRef] [PubMed]

3. Mamo, B.E.; Barber, B.L.; Steffenson, B.J. Genome-wide association mapping of zinc and iron concentration in barley landraces from Ethiopia and Eritrea. J. Cereal Sci. 2014, 60, 497-506. [CrossRef]

4. Ullrich, S.E. Barley: Production, Improvement, and Uses; John Wiley \& Sons: Manhattan, TX, USA, 2010 ; Volume 12.

5. Curry, A. The Gladiator Diet: How to eat, exercise, and die a violent death. Archaeology 2008, 61, 28-30.

6. Shewry, P.R. Barley: Chemistry and Technology; Elsevier: Amsterdam, The Netherlands, 2016.

7. Baik, B.-K.; Ullrich, S.E. Barley for food: Characteristics, improvement, and renewed interest. J. Cereal Sci. 2008, 48, $233-242$. [CrossRef]

8. Newman, C.W.; Newman, R.K. A brief history of barley foods. Cereal Foods World 2006, 51, 4-7. [CrossRef]

9. Sullivan, P.; Arendt, E.; Gallagher, E. The increasing use of barley and barley by-products in the production of healthier baked goods. Trends Food Sci. Technol. 2013, 29, 124-134. [CrossRef]

10. Quinde, Z.; Ullrich, S.E.; Baik, B.-K. Genotypic Variation in Color and Discoloration Potential of Barley-Based Food Products. Cereal Chem. J. 2004, 81, 752-758. [CrossRef]

11. AbuMweis, S.; Jew, S.; Ames, N. $\beta$-glucan from barley and its lipid-lowering capacity: A meta-analysis of randomized, controlled trials. Eur. J. Clin. Nutr. 2010, 64, 1472. [CrossRef]

12. Charalampopoulos, D.; Wang, R.; Pandiella, S.; Webb, C. Application of cereals and cereal components in functional foods: A review. Int. J. Food Microbiol. 2002, 79, 131-141. [CrossRef] 
13. Colasuonno, P.; Marcotuli, I.; Cutillo, S.; Simeone, R.; Blanco, A.; Gadaleta, A. Effect of barley chromosomes on the $\beta$-glucan content of wheat. Genet. Resour. Crop. Evol. 2020, 67, 561-567. [CrossRef]

14. Welch, R.M.; Graham, R.D. Breeding for micronutrients in staple food crops from a human nutrition perspective. J. Exp. Bot. 2004, 55, 353-364. [CrossRef]

15. Cakmak, I.; Ozkan, H.; Braun, H.J.; Welch, R.M.; Römheld, V. Zinc and iron Concentrations in Seeds of Wild, Primitive, and Modern Wheats. Food Nutr. Bull. 2000, 21, 401-403. [CrossRef]

16. Uauy, C.; Distelfeld, A.; Fahima, T.; Blechl, A.; Dubcovsky, J. A NAC Gene Regulating Senescence Improves Grain Protein, zinc, and iron Content in Wheat. Science 2006, 314, 1298-1301. [CrossRef] [PubMed]

17. Gepts, P. Plant Genetic Resources Conservation and Utilization: The Accomplishments and Future of a Societal Insurance Policy. Crop. Sci. 2006, 46, 2278-2292. [CrossRef]

18. Zohary, D.; Hopf, M.; Weiss, E. Domestication of Plants in the Old World: The Origin and Spread of Domesticated Plants in Southwest Asia, Europe, and the Mediterranean Basin; Oxford University Press on Demand: New York, NY, USA, 2012.

19. Bockelman, H.E.; Valkoun, J. Ullrich, Barley Germplasm Conservation and Resources. In Barley: Improvement, Production, and Uses; Wiley-Blackwell: Oxford, UK, 2010; pp. 144-159.

20. AACC. Approved Methods of the American Association of Cereal Chemists, 10th ed.; Cereals \& Grains Assn: St. Paul, MN, USA, 2000.

21. Manzanares, P.; Sendra, J. Determination of total $(1 \rightarrow 3),(1 \rightarrow 4)-\beta$-D-glucan in barley and malt flour samples. J. Cereal Sci. 1996, 23, 293-296. [CrossRef]

22. Pequerul, A.; Pérez, C.; Madero, P.; Val, J.; Monge, E. A rapid wet digestion method for plant analysis. In Optimization of Plant Nutrition; Springer: Berlin/Heidelberg, Germany, 1993; pp. 3-6.

23. Butler, D.; Cullis, B.; Gilmour, A.; Gogel, B. Mixed Models for S Language Environments, ASReml-R Reference Manual; VSN International Ltd.: Hemel Hempstead, UK, 2009.

24. Team, R.C. R: A Language and Environment for Statistical Computing; R Foundation for Statistical Computing: Vienna, Austria, 2016.

25. Bowman, A.W.; Azzalini, A. Package 'sm': Nonparametric Smoothing Methods (Version 2.2-5.6). 2018. Available online: http:/ / www.stats.gla.ac.uk/ \{\}adrian/sm (accessed on 23 September 2021).

26. Ehrenbergerová, J.; Belcredi, N.B.; Psota, V.; Hrstkova, P.; Cerkal, R.; Newman, C.W. Changes Caused by Genotype and Environmental Conditions in Beta-Glucan Content of Spring Barley for Dietetically Beneficial Human Nutrition. Plant Foods Hum. Nutr. 2008, 63, 111-117. [CrossRef]

27. Houston, K.; Russell, J.; Schreiber, M.; Halpin, C.; Oakey, H.; Washington, J.M.; Booth, A.; Shirley, N.; Burton, R.A.; Fincher, G.B.; et al. A genome wide association scan for $(1,3 ; 1,4)-\beta$-glucan content in the grain of contemporary 2-row Spring and Winter barleys. BMC Genom. 2014, 15, 907. [CrossRef]

28. Lazaridou, A.; Biliaderis, C.G.; Izydorczyk, M.S. Cereal $\beta$-glucans: Structures, Physical Properties, and Physiological Functions, in Functional Food Carbohydrates; CRC Press: Boca Raton, FL, USA, 2006; pp. 15-86.

29. Newman, R.K.; Newman, C.W. Barley for Food and Health: Science, Technology, and Products; John Wiley \& Sons: Hoboken, NJ, USA, 2008.

30. Yan, J.; Wang, F.; Yang, R.; Xiao, T.; Fahima, T.; Saranga, Y.; Korol, A.; Nevo, E.; Cheng, J. Natural Variation in Grain Iron and Zinc Concentrations of Wild Barley, Hordeum spontaneum, Populations from Israel. In Advance in Barley Sciences; Springer: Berlin/Heidelberg, Germany, 2013; pp. 169-183.

31. Ghandilyan, A.; Ilk, N.; Hanhart, C.; Mbengue, M.; Barboza, L.; Schat, H.; Koornneef, M.; El-Lithy, M.; Vreugdenhil, D.; Reymond, M.; et al. A strong effect of growth medium and organ type on the identification of QTLs for phytate and mineral concentrations in three Arabidopsis thaliana RIL populations. J. Exp. Bot. 2009, 60, 1409-1425. [CrossRef]

32. Hebelstrup, K.H. Differences in nutritional quality between wild and domesticated forms of barley and emmer wheat. Plant Sci. 2017, 256, 1-4. [CrossRef]

33. Dawson, I.; Russell, J.; Powell, W.; Steffenson, B.; Thomas, W.T.B.; Waugh, R. Barley: A translational model for adaptation to climate change. New Phytol. 2015, 206, 913-931. [CrossRef] [PubMed]

34. Han, F.; Ullrich, S.E.; Chirat, S.; Menteur, S.; Jestin, L.; Sarrafi, A.; Hayes, P.M.; Jones, B.L.; Blake, T.K.; Wesenberg, D.M.; et al. Mapping of $\beta$-glucan content and $\beta$-glucanase activity loci in barley grain and malt. Theor. Appl. Genet. 1995, 91, 921-927. [CrossRef] [PubMed] 